\title{
Coworking Space dengan Konsep Pencahayaan yang Dinamis
}

\author{
Fatimah Az-Zahro dan Asri Dinapradipta \\ Departemen Arsitektur, Fakultas Arsitektur, Desain dan Perencanaan, Institut Teknologi Sepuluh Nopember (ITS) \\ e-mail: asdina_p@arch.its.ac.id
}

\begin{abstract}
Abstrak-Cahaya merupakan elemen arsitektur yang sangat penting. Karena dengan cahaya, persepsi dan definisi akan suatu ruangan dapat terbentuk. Terdapat dua jenis cahaya berdasarkan sumbernya, yakni cahaya alami dan cahaya buatan. Pada beberapa dekade silam, cahaya alami atau daylight menjadi suatu komponen penting dalam perancangan arsitektur. Namun dengan penemuan pencahayaan buatan, penggunaan daylight semakin ditinggalkan dan bahkan cenderung dihindari karena sulit dikendalikan. Sedangkan di sisi lain, manusia adalah organisme yang kodratnya berada di ruang luar. Sehingga dengan merasakan nuansa ruang luar dan merasakan daylight manusia merasa seimbang secara psikologi dan secara biologi. Variabilitas dan kontras yang dimiliki daylight bukan hanya mutlak merupakan suatu permasalahan. Kedinamisan dari kontras antara cahaya matahari dan bayangan tersebut dapat memberi arousal atau pembangkit kepada manusia. Menurut teori psikologi lingkungan, dengan adanya arousal dari lingkungannya, produktivitas manusia menjadi meningkat. Oleh karena itu, bagaimana arsitektur dapat menghadapi dinamisasi pada daylight dan membuatnya menjadi stimulus untuk meningkatkan suasana hati serta produktivitas pengguna bangunan, namun tetap nyaman serta memenuhi kebutuhan dan harapan pengguna bangunan. Selain itu, karena daylight dapat memberi penanda akan waktu pada arsitektur, maka bagaimana kelak tiap saat atmosfer ruangan yang tercipta dapat merubah persepsi penggunanya bahwa ada banyak hal yang menarik dan berbeda di setiap harinya meskipun dengan rutinitas dan tempat yang sama. Metode yang digunakan adalah metode yang berkebalikan urutan tahapannya dengan metode penelitian Kynthia Chamilothori, Jan Wienold, dan Marilyne Andersen dalam menganalisa perancangan daylight pada suatu bangunan yang sudah ada.
\end{abstract}

Kata Kunci-Concept Based Method, Daylight, Dinamis, Perancangan Ruang Kerja, Psikologi Lingkungan.

\section{PENDAHULUAN}

$\mathrm{D}$ ALAM beberapa dekade, penggunaan daylight semakin ditinggalkan dan bahkan kini cenderung dihindari, khususnya di daerah beriklim tropis. Kemudian pencahayaan buatan menjadi satu-satunya penerangan yang digunakan karena kemudahan kendali yang dimiliki. Tantangan utama dalam perancangan daylight di dalam suatu arsitektur adalah sifat dinamis yang dimiliki daylight. Intensitas, arah, posisi, dan warna daylight selalu berubah sepanjang waktu mengikuti jalur pergerakan matahari dan tidak dapat dikendalikan. Selain itu, terdapat dinamisasi berupa kontras yang terbentuk antara cahaya yang sangat terang dan bayangan yang ditimbulkan daylight. Sedangkan di sisi lain, pada area di dalam bangunan, manusia memerlukan suatu kondisi pencahayaan yang dapat

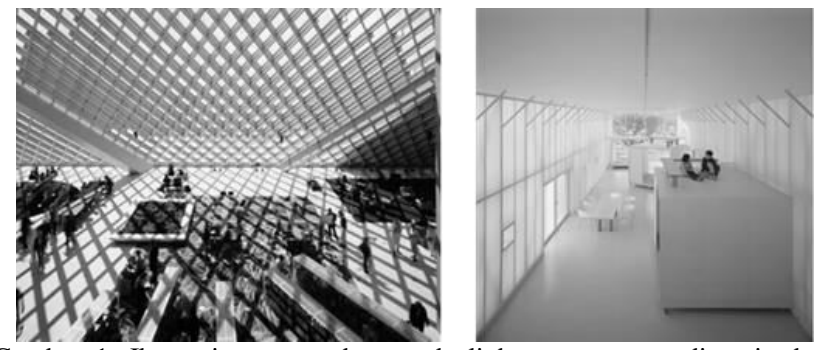

Gambar 1. Ilustrasi ruangan dengan daylight yang sangat dinamis dan ruangan dengan daylight yang sangat diffuse.

(Sumber: Pinterest, 2017)

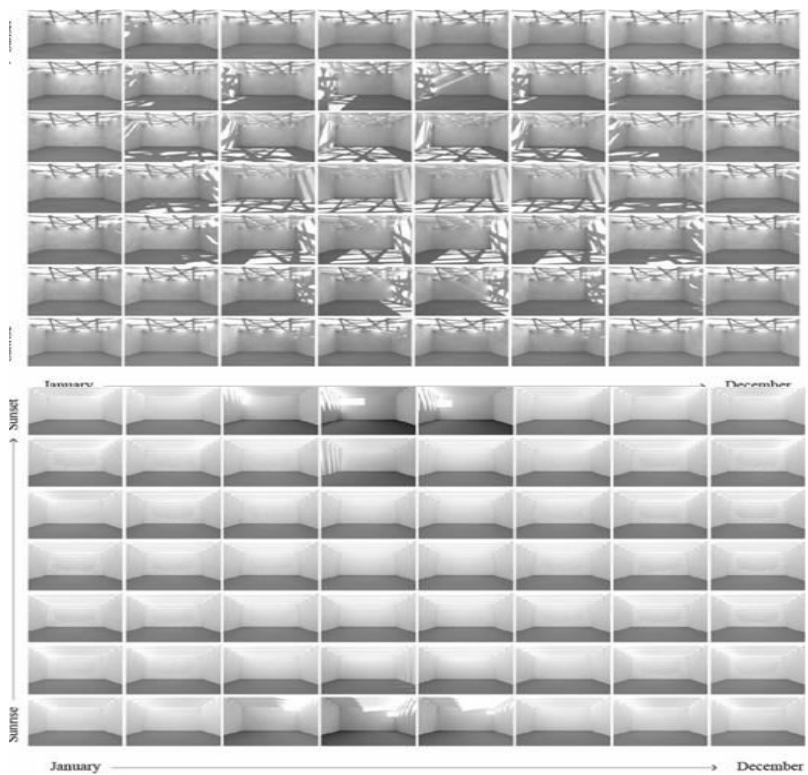

Gambar 2. Variabilitas dan perubahan pencahayaan seiring waktu matahari beredar dengan kontras yang tinggi dan rendah.

(Sumber: Siobhan Rockcastle dan Marilyne Andersen, 2015)

dikontrol dan memenuhi standar untuk dapat melakukan suatu pekerjaan. Tetapi pada kenyataannya, manusia tidak hanya membutuhkan ruangan yang dapat bekerja secara fungsional namun juga memerlukan ruangan yang mengakomodasi atmosfer yang dapat membuat mereka merasa tertarik dan puas [1].

Manusia adalah organisme yang kodratnya berada di ruang luar. Sehingga dengan merasakan nuansa ruang luarlah ia merasa seimbang secara psikologi dan secara biologi. Kekurangan akses akan daylight dapat menyebabkan manusia tertekan dan depresi [2].

Maka idealnya pencahayaan yang digunakan dalam arsitektur adalah perpaduan antara daylight dan cahaya buatan. 


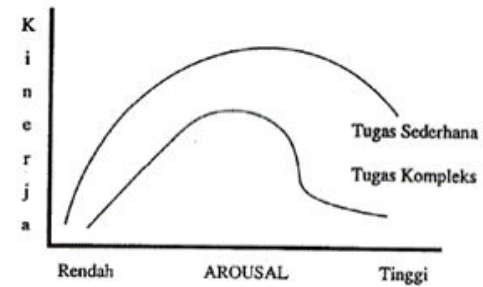

Gambar 3. Hukum Yerkes dan Dodson

(Sumber: Elearning.gunadarma.ac.id)

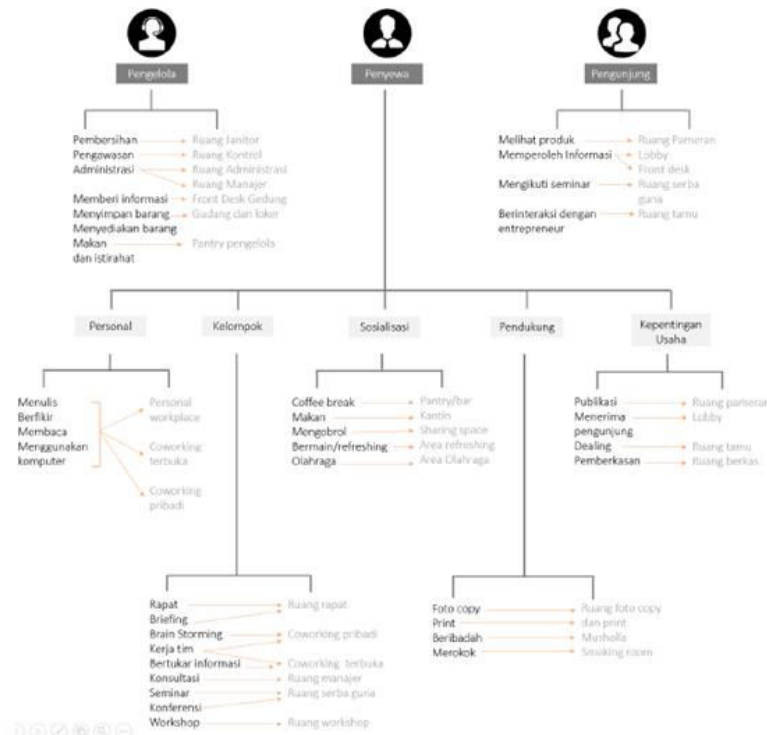

Gambar 4. Bagan daftar aktivitas beserta ruangan yang dapat mengakomodasi.

(Sumber: Ilustrasi penulis, 2017)

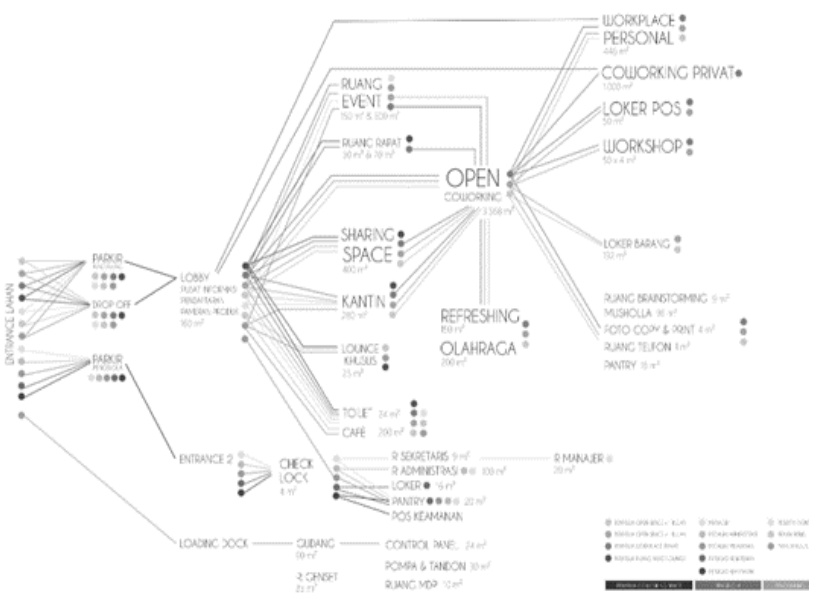

Gambar 5. Organisasi ruang.

(Sumber: Ilustrasi penulis, 2018)

Karena daylight tidak dapat sepenuhnya tergantikan oleh pencahayaan buatan. Arsitek dapat memanfaatkan daylight untuk membuat ritme dan tatanan yang berbeda dalam suatu ruangan sehingga dapat memberi atmosfer yang berbeda-beda.

Berdasarkan sejumlah penelitian, daylight banyak diasosiasikan dengan pengaruh baik berupa peningkatan well being, performa, dan produktivitas. Suatu pernyataan yang diungkapkan oleh neurological and biological research mengindikasikan bahwa akses terhadap daylight dan interaksi dengan manusia dapat meningkatkan produktivitas. Sehingga
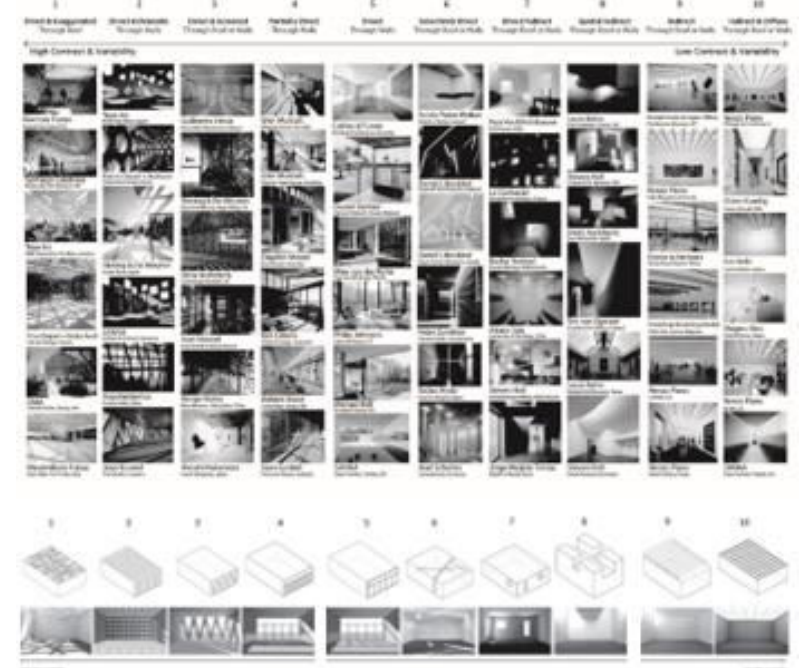

Gambar 6. Matriks strategi pemasukan daylight yang diurutkan dari yang paling dinamis (kontras) hingga yang paling tidak dinamis (merata). (Sumber: Siobhan Rockcastle dan Marilyne Andersen (2015))

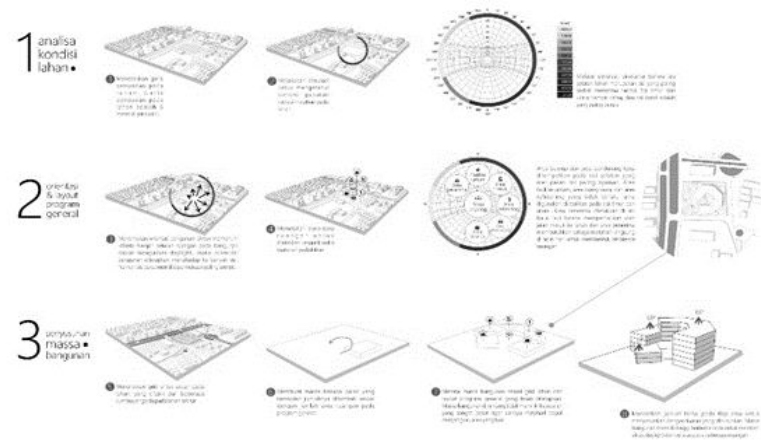

Gambar 7 Transformasi bentuk

(Sumber: Ilustrasi penulis, 2018)

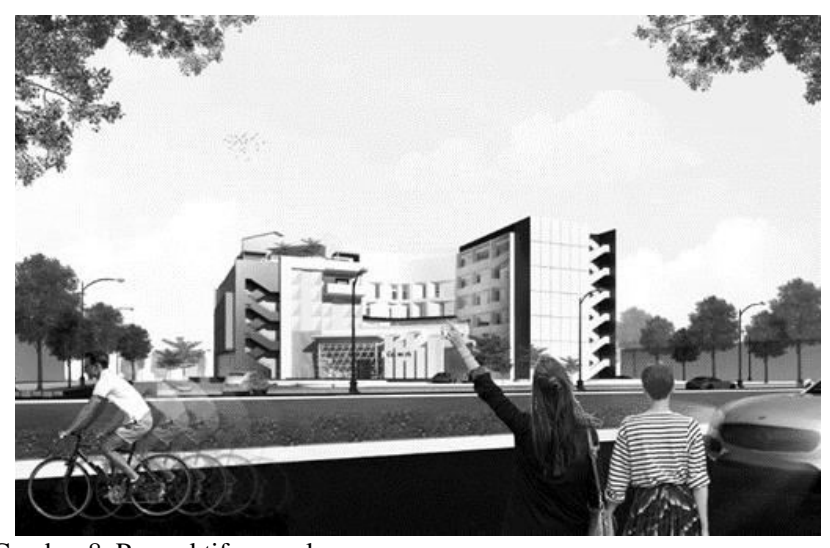

Gambar 8. Perspektif normal

(Sumber: Ilustrasi penulis, 2018)

pada perancangan ini dipilih tipologi arsitektur berupa ruang kerja karena erat kaitannya dengan kebutuhan akan produktivitas yang tinggi.

\section{METODE PERANCANGAN}

\section{A. Pendekatan Desain}

Titik fokus pada perancangan ini adalah bagaimana hubungan antara lingkungan (dalam hal ini dibatasi pada daylight) dengan arsitektur dan dengan pengguna bangunan, 


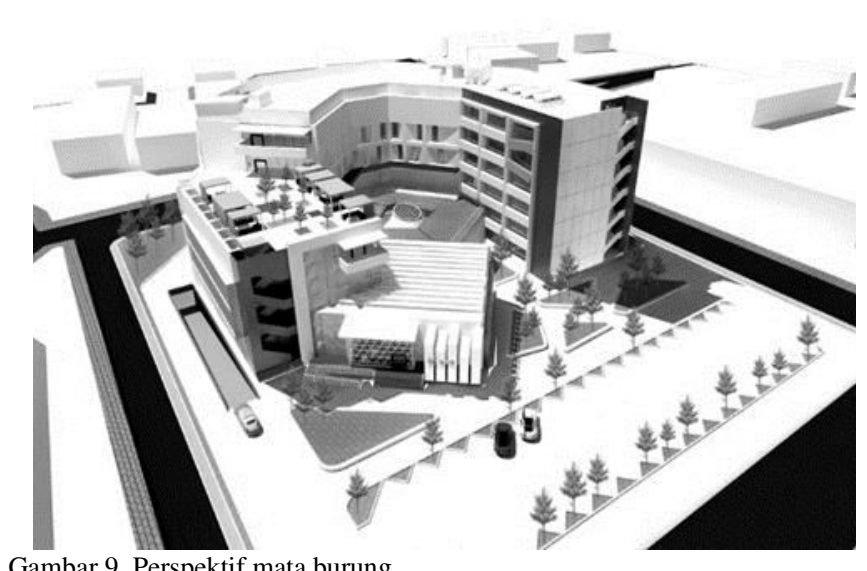

Gambar 9. Perspektif mata burung

(Sumber: Ilustrasi penulis, 2018)

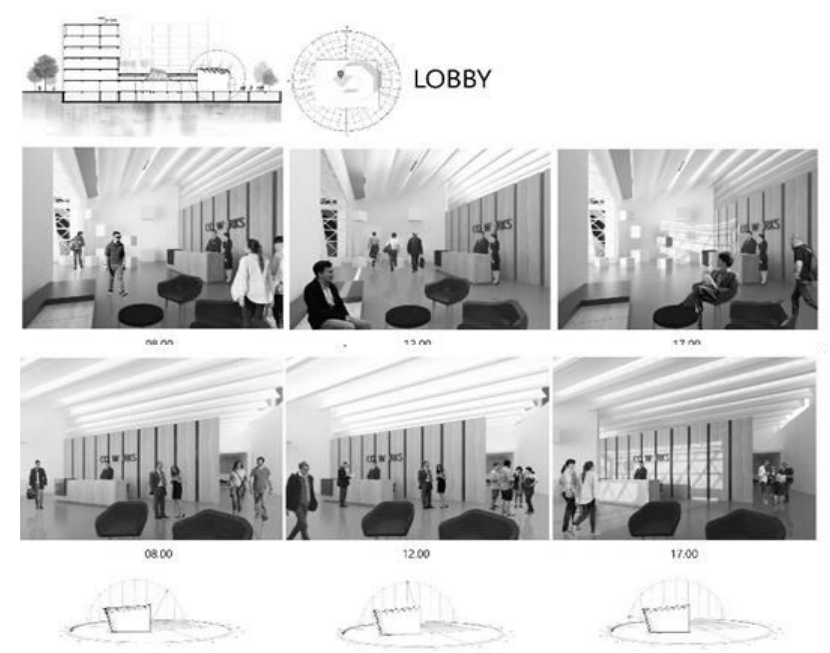

Gambar 10. Desain lobi

(Sumber: Ilustrasi penulis, 2018)

yakni bagaimana lingkungan dan arsitektur mempengaruhi dan mengubah persepsi pengguna. Kemudian bagaiaman respon emosi yang tercipta serta pengaruhnya terhadap inovasi, kreativitas, serta produktivitas dari pekerja. Oleh karena itu, pendekatan yang digunakan adalah psikologi lingkungan. Terdapat beberapa teori pendekatan dalam psikologi arsitektur. Pendekatan teori psikologi lingkungan yang akan digunakan pada perancangan adalah teori arousal (pembangkit) karena keterkaitannya dengan faktor pemicu kinerja manusia.

Arousal dipengaruhi oleh tingkat umum dari rangsangan yang mengelilingi individu. jika yang dihadapi adalah hal yang tidak ada-apa apanya, maka akan membuat bosan dan tertidur. Dalam psikologi lingkungan, hubungan antara arousal dengan kinerja seseorang dapat dijelaskan seperti berikut: Tingkat arousal yang rendah akan menghasilkan kinerja yang rendah. Makin tinggi tingkat arousal akan menghasilkan kinerja yang tinggi pula.

Pernyataan di atas menjadi dasaran bahwa kehadiran arousal memang dapat meningkatkan kinerja seseorang, berbeda dengan tidak adanya arousal sama sekali. Tetapi dalam pengaplikasiannya, tingkatan arousal sangat bergantung pada jenis aktivitas yang dilakukan. Tidak semua

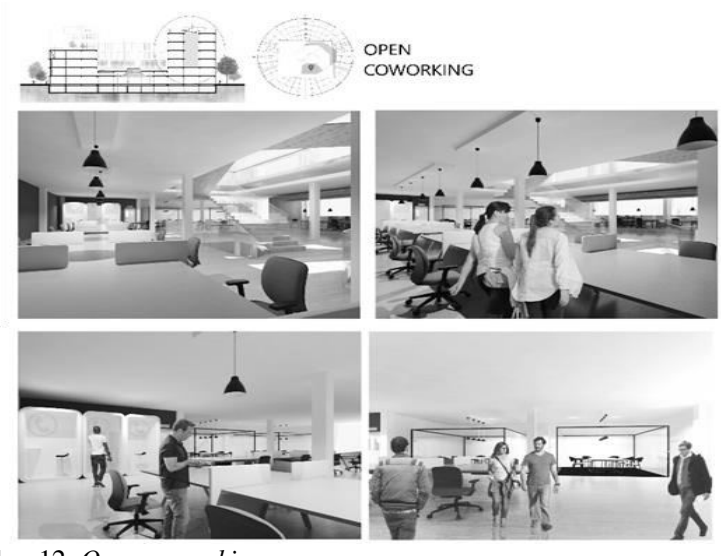

Gambar 12. Open coworking space

(Sumber: Ilustrasi penulis, 2018)
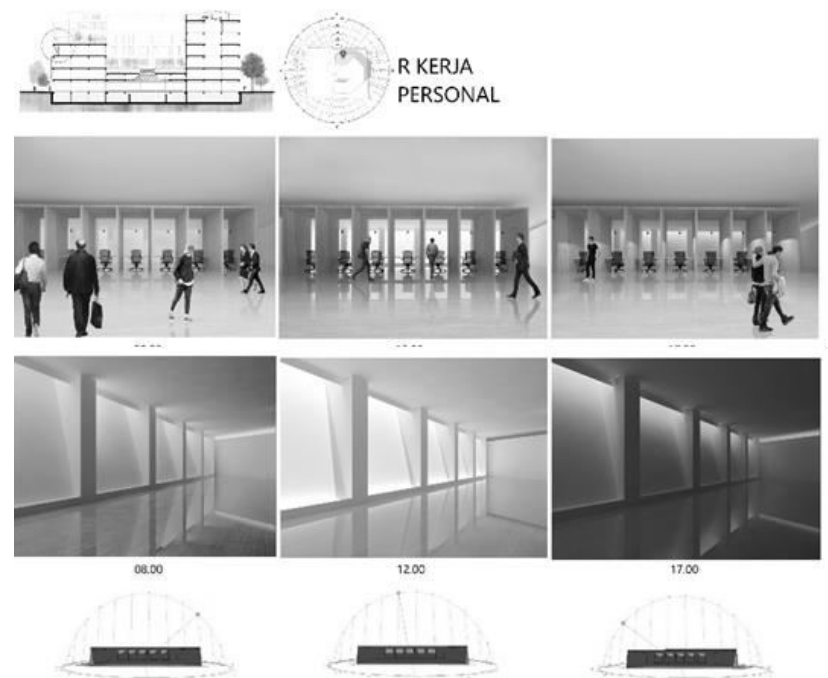

Gambar 13. Area kerja personal

(Sumber: Ilustrasi penulis, 2018)

aktivitas dapat diberi arousal yang tinggi. Pada teori lebih lanjut, dibahas mengenai grafik hubungan antara tingkat arousal dengan peningkatan kinerja yang terjadi. Hubungan tersebut dinamakan Hukum Yerkes dan Dodson [3].

\section{B. Metode Desain}

Perancangan ini bermula dengan mengangkat konsep pencahayaan yang dinamis dari isu mengenai 'daylight dan arsitektur'. Dengan begitu, perancangan ini menggunakan metode concept-based.

1. Metode untuk formal

Metode yang digunakan untuk membuat bentukan bangunan adalah sebuah metode yang telah diterapkan pada sebuah jurnal perancangan bangunan [4]. Adapun langkahlangkah yang dilakukan terbagi menjadi tiga tahap utama sebagai berikut:

a. Menganalisa kondisi cahaya matahari pada lahan. Hal yang perlu diamati adalah pada sisi mana matahari memiliki intensitas terbesar dan pada sisi mana yang terendah atau dengan kata lain, sisi yang paling nyaman. Selain itu, perlu juga dianalisa mengenai kondisi pembayangan yang diakibatkan oleh bangunan dan objek lain di sekitar lahan. 

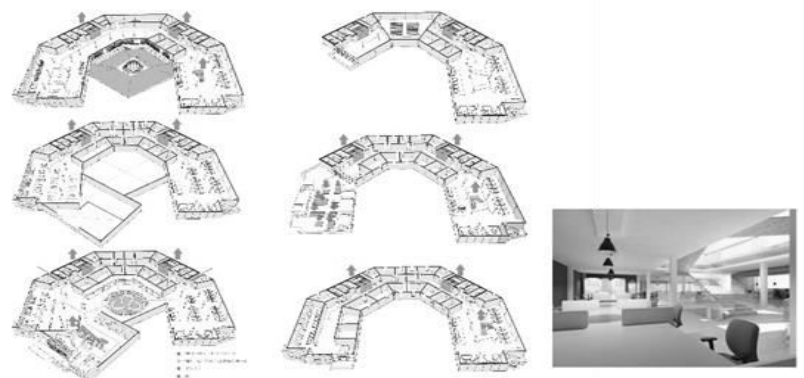

Gambar 14. Sirkulasi pada bangunan (Sumber: Ilustrasi penulis, 2018)

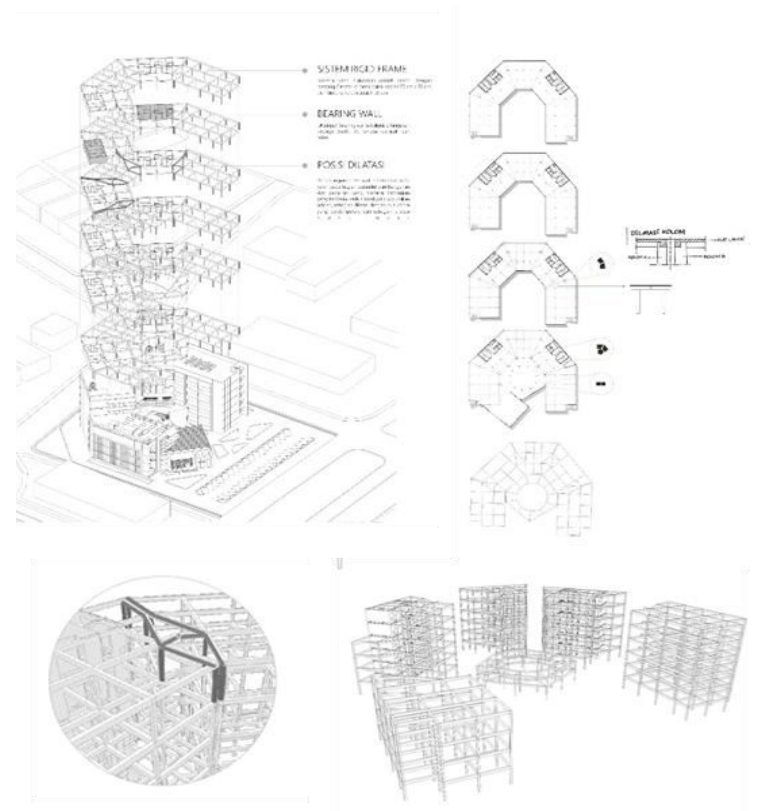

Gambar 15. Struktur pada bangunan

(Sumber: Ilustrasi penulis, 2018)

b. Menentukan orientasi bangunan dan layout program ruang secara general. Pada tahap ini, beberapa ruangan dikelompokkan menjadi zona-zona, kemudian diletakkan pada lahan sesuai dengan kebutuhan dan kondisi cahaya matahari yang ada. Zona atau area yang digunakan oleh banyak orang dan dalam jangka waktu yang lama diletakkan pada sisi dengan intensitas matahari yang paling rendah (paling nyaman). Kemudian, setiap zona diletakkan sedemikian rupa agar tidak tertutup bayangan yang dihasilkan oleh objek lain di sekitar lahan.

c. Menyusun masa bangunan. Setelah menata layout secara general, masa bangunan dapat dibentuk sesuai tatanan tersebut dan dengan luasan serta tinggi sesuai kebutuhan masing-masing zona ruangan. Bentuk masa bangunan juga dapat dicoak, digeser, dan lain sebagainya, menyesuaikan dengan kebutuhan bukaan pada suatu ruangan.

2. Metode untuk program

a. Menetapkan siapa saja pengguna bangunan. Pengguna bangunan meliputi: penyewa coworking space, pengelola, dan pengunjung.
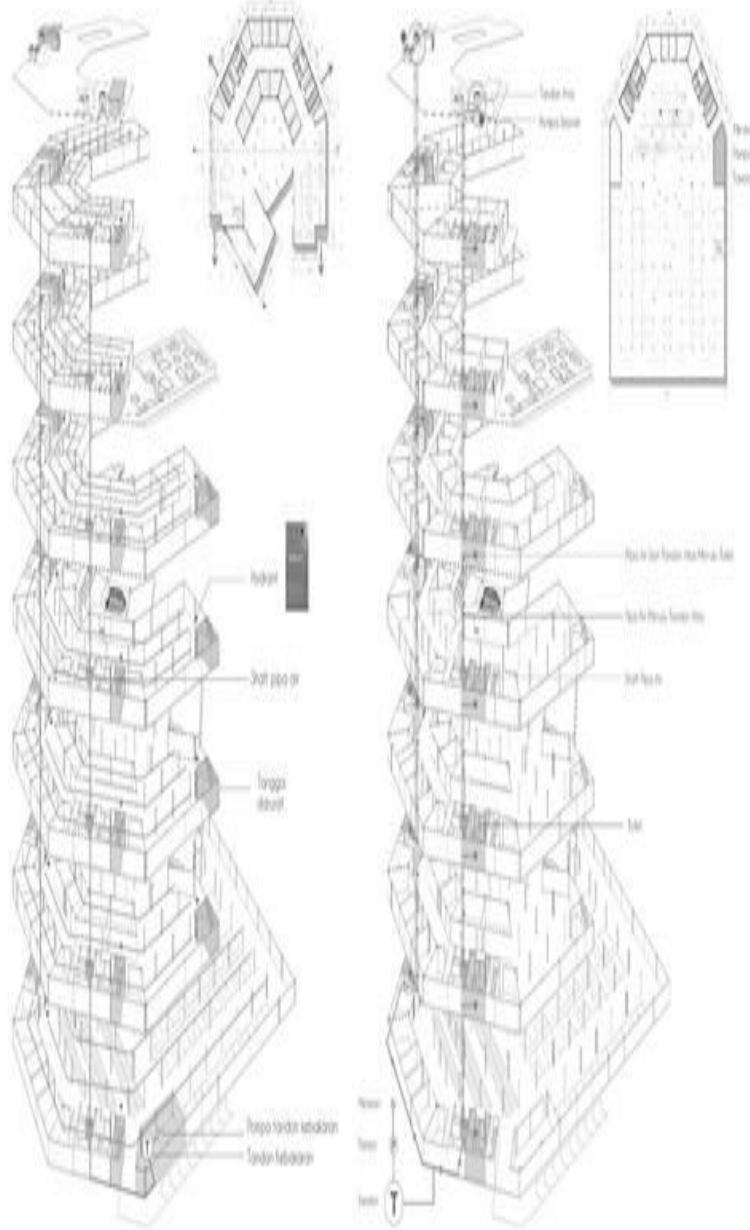

Gambar 16. Proteksi ancaman kebakaran dan sistem air bersih (Sumber: Ilustrasi penulis, 2018)

b. Dari tiap pengguna, dilakukan pendataan mengenai aktivitas apa saja yang dapat dilakukan di dalam bangunan rancang.

c. Kemudian dari tiap aktivitas, diputuskan ruanganruangan apa saja yang dapat mewadahi. Lalu melakukan pendataan mengenai standar dan luasan yang dibutuhkan oleh tiap ruangan.

d. Mencari beberapa preseden coworking space untuk mengetahui tingkatan privasi tiap jenis ruangan

e. Terakhir, melakukan positioning dari setiap kelompok ruangan tersebut dengan pertimbangan zonasi kebisingan serta privasi.

3. Metode untuk konsep

Metode yang digunakan adalah metode yang berkebalikan urutan tahapannya dengan metode sebuah penelitian yang menganalisa perancangan daylight pada beberapa bangunan yang sudah ada [5].

a. Menentukan kriteria tiap ruangan dan aktivitas, apakah termasuk kegiatan bekerja, sosial, atau bekerja dan sosial, sehingga kemudian diketahui jenis arousal apa yang dibutuhkan. Apakah tinggi, sedang, atau rendah.

b. Setelah diketahui jenis arousal yang dibutuhkan, langkah selanjutnya adalah melihat matriks pada hasil penelitian [5]. Lalu memilih salah satu teknik yang sesuai dengan tingkat kontras yang dibutuhkan.

c. Merancang daylight sesuai teknik tersebut dengan menganalisa dari mana cahaya akan datang (dengan 
melihat azimuth serta altitude matahari pada sunpath) dan ke mana ia akan mendarat.

\section{HASIL DAN EKSPLORASI}

\section{A. Konsep Bentuk}

Untuk membentuk masa bangunan, dilakukan dengan tiga langkah utama, yakni analisa kondisi pencahayaan matahari pada lahan, kemudian menetapkan orientasi dan layout program secara general, dan yang terakhir adalah menyusun masa bangunan. Setelah masa bangunan diatur, kemudian dilakukan perancangan bukaan pada tiap ruangan sesuai kebutuhan.

\section{B. Konsep Desain Pencahayaan}

Kualitas cahaya yang datang dari sumber cahaya memberi kontribusi besar untuk pencapaian nilai luminansi yang sesuai pada permukaan ruangan dan mempengaruhi tingkat kecerahan pada ruangan. Membahas lebih lanjut, beberapa penelitian membuktikan bahwa permukaan ruangan yang memberi dampak paling besar untuk tingkat kecerahan pada ruangan adalah langit-langit dan permukaan vertikal (meliputi dinding dan komponennya), termasuk juga elemen sunscreen yang digunakan pada tampang bangunan. Penggunaan sunscreen pada bangunan dapat mempengaruhi kualitas pencahayaan dengan signifikan [6]. Oleh karena itu, dalam merancang pencahayaan yang dinamis, elemen arsitektur yang fokus dieksplorasi adalah pada sisi langit-langit, permukaan vertikal ruangan, serta elemen sunscreen pada tampang bangunan. Bentuk, jenis material, dan tingkat transparansi sunscreen mempengaruhi kualitas daylight yang masuk ke dalam bangunan secara signifikan [7].

Sunscreen memiliki peranan yang penting pada bangunan yang dirancang dengan mengakomodasi daylight, khususnya untuk daerah beriklim tropis yang panas seperti Indonesia. Karena sunscreen dapat membantu mengurangi atau menghalangi panas matahari namun tetap dapat membuat cahaya matahari masuk ke dalam bangunan [7].

Ruangan dengan aktivitas sosial seperti lobi, ruang makan, café, area olahraga serta refreshing dirancang dengan dinamisasi pencahayaan yang tinggi (arousal tinggi). Ruangan dengan aktivitas sosial-bekerja seperti area sharing dirancang dengan dinamisasi pencahayaan yang sedang (arousal sedang). Ruangan dengan aktivitas bekerja seperti open coworking, coworking privat, dan area kerja personal dirancang dengan dinamisasi pencahayaan yang rendah (arousal rendah).

Pada lobi bangunan, cahaya masuk melalui atap dan jendela. Cahaya matahari siang yang masuk melalui skylight dihambat

oleh bentukan sirip sehingga tidak dapat mengenai pengguna bangunan, namun terang cahayanya tetap dapat terlihat melalui sirip-sirip tersebut. Sedangkan sore hari, ketika matahari datang dengan sudut yang rendah dan tajam, serta cahaya tidak menyengat, cahaya matahari masuk secara langsung dari jendela lobi. Area sharing yang terletak di tengah bangunan menggunakan skylight berbentuk corong. Teknik tersebut merupakan teknik direct indirect, seperti pada matriks penelitian yang telah disebutkan. Dengan bentukan corong, cahaya langsung yang masuk sedikit karena dari lubangan yang kecil pada sisi atas, sedangkan terang yang didapat jauh lebih lebar melalui sisi bawah corong. Area open coworking space menggunakan teknik pemasukan daylight secara tidak langsung, yakni cahaya matahari tidak masuk secara langsung, namun melalui pantulan sirip-sirip skylight. Area kerja personal juga menggunakan teknik pemasukan daylight secara tidak langsung. Cahaya matahari hanya mengenai bidang yang disediakan sehingga cahaya hanya dapat dilihat oleh pengguna bangunan tanpa mengenai pengguna secara langsung.

\section{Konsep Sirkulasi}

Sirkulasi pada bangunan adalah linear sehingga dengan begitu pengguna bangunan akan sering saling berpapasan satu sama lain. Dengan begitu akan lebih mudah untuk bersosialisasi. Pada area open coworking terdapat tangga antar lantai sehingga pengguna open coworking space dapat berpindah antar lantai dengan lebih cepat

\section{Eksplorasi Teknis}

Sistem struktur yang digunakan adalah rigid frame dengan material beton. Pada bagian tekukan bangunan, terdapat dilatasi. Dilatasi yang digunakan ada dua jenis, yakni dilatasi dengan dua kolom yang berjejer dan dilatasi dengan balok kantilever. Pada bagian bangunan yang memiliki ketinggian berbeda juga diberi dilatasi. Terdapat bearing wall pada bangunan yang sekaligus digunakan untuk menempatkan lift, toilet, shaft kering dan shaft basah, ruang janitor, dumb waiter, dan tangga darurat. Tangga kebakaran ditempatkan pada sisi ujung dan tengah bangunan dengan jarak antar tangga sepanjang 40 meter. Bangunan dilengkapi dengan tandon dan pompa air khusus proteksi kebakaran pada basement. Air mengalir melalui pipa pada shaft basah di dekat kamar mandi untuk menuju sprinkler dan hydrant. Untuk pemenuhan air bersih, bangunan dilengkapi oleh tandon bawah dan tandon atas. Air dari PDAM ditampung dalam tandon bawah, kemudian dipompa menuju tandon atas. Kemudian dari tandon atas, air turun menuju kran air. Untuk lantai 6 dan 5, diperlukan pompa booster ketika menyalurkan air dari tandon atas ke kran karena pada tandon atas tidak dilengkapi dengan Menara tandon. Sedangkan untuk lantai 4 ke bawah, air dapat mengalir dengan mengandalkan gaya gravitasi. Pipa air vertikal diletakkan dalam shaft basah, bersama dengan shaft pipa air kebakaran.

\section{KESIMPULAN}

Bangunan perkantoran yang dirancang dengan daylight beserta dinamisasinya dapat memberi efek baik kepada pengguna bangunan seperti merasakan atmosfer yang lebih hidup, meningkatkan mood dan produktivitas, serta meredakan stres. Untuk memanfaatkan daylight secara optimal dalam bangunan, tebal bangunan tidak dapat terlalu dalam. Kemudian atrium dapat membantu akses masuknya daylight. Selain itu, ketinggian bangunan juga dibuat berbeda-beda untuk menambah luas bidang yang dapat terpapar daylight. Dinamisasi pada daylight dikontrol dengan cara merancang teknik pemasukan daylight secara kontekstual, sesuai dengan jenis aktivitas yang ada di dalamnya. Setiap jenis teknik pemasukkan daylight mengacu pada penelitian sehingga efek yang ditimbulkan untuk pengguna telah diprediksi oleh hasil 
penelitian tersebut. Kemudian untuk membuat pengguna menyadari kehadiran, dinamisasi, serta perubahan daylight sehingga pengguna dapat merasakan atmosfer yang berbeda meskipun berada di tempat yang sama- disediakan bidang tempat cahaya dan bayangan itu jatuh. Area tersebut menjadi arah pandang tempat duduk pengguna bangunan.

\section{DAFTAR PUSTAKA}

[1] M. Andersen, "Daylighting Performance: A Dynamic and Multidimensional Challenge," in Proc. Light Lecture, 2016.

[2] C. C. Gomes and S. Preto, "Should the Light be Static or Dynamic," in Proc. 6th International Conference on Applied Human Factors and Ergonomics and the Affiliated Conferences, 2015.

[3] P. Hendro, "Pengantar Psikologi Lingkungan," Jakarta, 2017.
[4] O. Skidmore and M. LLP, "Form Follows the Sun: Hill County SEZ Office Complex," in Proc. PLEA 25th Conference on Passive and Low Energy Architecture, 2008.

[5] K. Chamilothori, J. Wienold, and M. Andersen, "Daylight Patterns as A Means to Influence the Spatial Ambience: A Preliminary Study," 2016.

[6] A. Dinapradipta and J. Krisdianto, "Brightness Performance of Office Interior Due to Room's Window Components Configuration," Dimens. J. Archit. Built Environ., vol. 44, no. 2, 2017.

[7] A. Dinapradipta, E. Sudarma, I. Defiana, and C. Erwindi, "Interior Shadings for Office Indoor Visual Comfort in Humid Climate Region," in Proc. Friendly City 4 IOP Conf. Series: Earth and Environmental Science, 2018. 